\title{
Traditional Festivities in North Istria in Terms of Authenticity and (Dis)Continuity
}

\author{
Katja Hrobat Virloget \\ University of Primorska, Faculty of Humanities, Slovenia \\ katja.hrobat@fhs.upr.si \\ Petra Kavrečič \\ University of Primorska, Faculty of Humanities, Slovenia \\ petra.kavrecic@fhs.upr.si
}

This article is derived from the project Turizmo Ištriano (Programme Las Istre), the main aim of which was to observe the intangible heritage of North Istria from an ethnological point of view, within which our focus was on traditional festivities. Instead of a tourist valorisation 'from above', the focus of this ethnologic research was directed towards the perceptions 'from below', on how people perceive the local intangible heritage. Questions were raised about the so-called 'authenticity', continuity, or discontinuity of the traditions and their relation to tourism. The research has shown that a significate element of the break of tradition of šagre can be found in the massive migrations after WwII in the rural part of Istria, which is related to the consequences of the so-called 'Istrian exodus.' It has also been shown how vital it is for the tradition to survive is its adaptation to the needs of the present. It was shown that people do differentiate between šagra (local character, no tourist promotion), and the 'massive' events that are attempting to attract tourists by selling products, presentation of 'old days' customs, traditional dresses, etc. that represent a 'staged authenticity'.

Keywords: festivities, šagra, tradition, (dis)continuity, North Istria

https://doi.org/10.26493/2335-4194.12.109-120

\section{Introduction: On Tradition and Village Festivities Šagre}

The reflections in this article are derived from the project Turizmo Ištriano (Programme LAS Istre) ${ }^{1}$ in which the primary aim was to observe the intangible heritage of North Istria ${ }^{2}$ from an ethnological point of

\footnotetext{
${ }^{1}$ The programme LAs Istre (Lokalna akcijska skupina za območje občin Ankaran, Izola, Koper and Piran) is a publicprivate partnership with the aim of acting jointly in the implementation of the Local Development Strategy of a given area and to obtain support from EU funds.

${ }^{2}$ The part of Istria which lies today in Slovenia. Because of the multiculturality and official Italian-Slovenian bilingual-
}

view, within which our focus was on traditional festivities. The interest was also to study the correlation between traditional local festivities and the tourism industry, identifying those elements of intangible heritage that could be positioned and promoted in the tourism offerings of Northern Istria. For this purpose, we have prepared a list of intangible heritage, focusing on annual customs (tradition) and habits in the studied region. We have given evidence that the most appealing customs for tourists are the festivals, known

ism of the region, we prefer to call it North Istria and not Slovenian Istria. 
as šagre. This traditional event was also studied in the previous project Heritage Live: Living, Lived, Revived Cultural Heritage (Programme ipa Slovenia-Croatia 2007-2013), in which particular attention was given to the history of such events (from the 16th to the 19th century) and the so-called 'authenticity' of the intangible heritage of North Istria (see Panjek 2012).

In the frame of this project, we have decided, that instead of a tourist valorisation 'from above' we will look into peoples' perception of intangible heritage and how is a tourist promotion of these events seen by the locals. Are tourists welcome at all? Or are these festivities mostly meant for inhabitants from the area? Which festivities potentially have a tourist interest and want to attract tourists (foreign)? Are there such festivities in this area? Is this more common for new, recently 'invented' festivities or also for 'traditional' ones? These reflections have brought out questions of the so-called 'authenticity' and continuity or discontinuity of the intangible heritage in North Istria, which had not been previously explored.

The intention linked to the ethnological part of the project would be to preserve the intangible heritage of Istria and present it within a tourism framework. As mentioned above, one of the aims is to elaborate a list of intangible heritage of North Istria focusing on traditional calendar festivities, where the focus was on the kind of village festivities called šagre. We have concentrated on the calendar festivals in Northern Istria, conducting ethnographic fieldwork at traditional and new events (šagre, celebrations related to memorial events of WWII, 1st May etc.). During the fieldwork, we have though decided to focus mostly on $\check{s} a-$ gre, since this has been and is still today one of the most widespread traditions in the field of calendar festivities and it has not received sufficient attention in the professional/scientific literature.

Ethnologists are well aware that traditions evolve and adapt to new contemporary needs of the present in order to be meaningful to members of a particular community; they also disappear when they lose meaning for the people and their collective identity. Once they cease to be changeable, they disappear and become 'fossilised' as heritage (Sims \& Stephens, 2005; Kockel, 2008). Tradition is not a product of the past to be accepted passively by successors, but a 'viewpoint,' a contemporary interpretation of past events by strictly contemporary criteria. Every continuity contains change, constructions, inventions, therefore continuity is not synonymous of sameness, but changeability (Kockel, 2008, p. 12; Lenclud, 2004, pp. 124-126, 131).

This article aims to reflect on the elements of (dis)continuity in North Istria, especially in the case of the village festivals, called šagre, which when speaking of the traditional village festivities, were the most discussed by our interlocutors. Usually a nostalgic picture of the countryside prevails, portrayed as 'rural idyll', where 'frozen' tradition is locked in time and space (Poljak Istenič, 2013, pp. 108-110). This would also be the case of the observed cases in North Istria. However, if the tradition exists because it makes sense to the community, it gives the basis for identity constructions, it unites members of the community, it brings economic advantages, etc. (Poljak Istenič, 2012; Fakin Bajec, 2011, pp. 287-291), why have certain traditional festivities in North Istria disappeared, and why others have persisted?

\section{Methodology}

The interest of this paper was to study the changing of tradition in the rural area of North Istria in the period following WWII, when political, economic, social, and population changes significantly affected this area. How did these changed circumstances affect the local tradition, why and how did it change? As already explained in the introduction, we have decided to concentrate our study from a different perspective. Our focus was on the peoples' perception of intangible heritage and their relation towards its tourist promotion.

If traditionality is conceived as the kind of events with a long-lasting continuity (Habinc, 2014, pp. 114, 125; Poljak Istenič, 2008, p. 71), 'the continuity of the past in the present' (Lenclud, 2004, p. 125) or 'a set of phenomena that have been passed on from generation to generation and finally settled in the life of a community' (Poljak Istenič, 2012, p. 77), our aim was to observe (dis)continuity elements and the reasons for them.

The method implied was ethnographic. Interviews 
were conducted with older persons from North Istria, above the age of 60 , focusing mostly on their perception of local calendar festivities, what they like or dislike and what is their opinion about changes through time and their view about the commercialisation (tourism) of these events. The interest was to question their point of view about issues such as the transformation, disappearance, and revitalisation or invention of festivities. Since šagre are one of the most well-known and common festivities in the studied area, we dedicated most attention to these events. While talking with our interlocutors, many other questions were raised, especially related to 'authenticity', continuity and discontinuity. Those phenomena manifested due to specific historical circumstances, following the Second World War in Istria.

The second part of the research is derived from the anthropological method of participant observation, in which students and researchers were observing the performance of nine festivities (šagre) in the current year (2019), interviewing organizers of the events, but also questioning visitors about their opinion, attitudes, etc. The study also concentrated on scientific and professional literature.

\section{Continuity Elements and 'Authenticity'}

Šagre, sometimes opasilo, semenj, fiera, etc. in Istria, as well as in other places in Slovenia, also known as žegnanje, proščenje, shod, etc., have many meanings. The root of the word and history suggest that the word originally signified dedication, i.e. commemoration of the anniversary of the consecration of the church. As observed by Muženič (2012, pp. 88-89), the celebration is not performed on the annual day itself, but on the Sunday that follows. In the past, the duration was commonly from one to three days. The most important day was Sunday, starting with the Holy Mass, following by the procession through the village. A smaller celebration took place also on Monday and/or Tuesday, rarely on Saturday. As an informant said: 'the preparations of the stage for dancing usually took place on Saturday, the šagra was organized on Sunday [...] we started late in the afternoon. ${ }^{3}$ As

${ }^{3}$ Interview by Petra Kavrečič, 22th August 2019. known, today's šagra takes place from Friday to Sunday. The majority of visitors are coming on Saturday. ${ }^{4}$

People slowly transferred the word to other ecclesiastical events, such as the consecration of a chapel, an altar, the restoration of a church, etc., and slowly it was transferred to the local church patron saint, e.g., a saint or saint to whom the church is dedicated. In the word for 'fair,' Slovenian semenj or Italian fiera, a second meaning is retained: gathering people with a prominent trading function (Vilfan, 1945, pp. 18-19; 1996, 155; Kuret, 1998, p. 143; Hrobat Virloget, 2012, p. 14). In some places there are also two (Vidali, 1989, p. 58) or three šagre (Sv. Peter, Škofije) a year, which could be explained by the loose meaning of the festivity, which extends from the celebration of the patron saint to the dedication of the church and its various parts (Hrobat Virloget, 2012, p. 14) or to several churches or chapels in the village (e.g,. Škofije). The village of Škofije remains divided in the upper (Zgornje Škofije) and lower village (Spodnje Škofije). The two settlements (or even part of the settlements) organised a šagra each or even more than one šagra. The upper village (2nd and 3 rd Škofija) organized two celebrations. One was dedicated to the nearby church of Kristus Kralj (Christ the King), celebrated still today at the end of November. The local priest organizes the celebration, with the procession, accompanying the statue of Christ the King across the central part of the village. ${ }^{5}$ The other was organised in summer months (the second Sunday of July) and was not based upon any religious celebration.

The sole organization of šagre in the past has already been described in detail. We will just briefly present the main characteristics. The organisation was in the hands of the young men of the village. They were in charge of the preparation of the dance floor, stage and selection of musicians, permissions, wine sale, ticket sale, the organization of the dance, where a spe-

\footnotetext{
${ }^{4}$ This is understandable in the present way of living. People are usually at to work during the week, which is mostly situated in the nearby urban centres. The weekend represents 'the free days,' so the festivity has adjusted to present needs. ${ }^{5}$ Interview by Petra Kavrečič, 22th August 2019 and Župnija Koper (B. d.).
} 
cial symbolic function was linked to the so-called 'first dance' etc. (Hrobat Virloget, 2012, pp. 15-18; Ciglič, 1981; Kuret, 1998, p. 153; Koštiál, 2005, p. 209). An informant had a humorous comment on the 'old' way of advertisement: 'one week before "šagra" the Yugoslavian flag was put on the highest point. It was an old oak tree above Truške by us ... Facebook on the tree augh.'

People managed to adjust to various changes. As seen in this case, it regarded a specific political situation. Since Istrians experienced five different change of states (from Austro-Hungarian empire, the Kingdom of Italy, Provisional Government of the Free Territory of Trieste (Zone A and B), Yugoslavia, tp Slovenia/Croatia) during the 2oth century, the choice of the flag depended upon the temporary state powers. An informant commented on the period following WWII, when the territory has been divided into two zones (Zone A and B of the Free Territory of Trieste (1947-1954)). Since Škofije was a village closer to the border (Cunja, 2004), the inhabitants had to adjust to this situation. As explained by an interlocutor from Škofije: 'after the war, arches were placed ... in Spodnje Škofije ... a magnificent arch made of juniper ... on the Italian side ... on the Yugoslavian side, a knife was in our flags ... but the arch on the Zgornje Škofije was not that magnificent.'

On the day of šagra, all the village was decorated, houses' interior was repainted, in some towns (e.g., Piran) handmade fabrics and ivy decorations in the streets were made, etc. (Hrobat Virloget, 2012, pp. 1618). In contrast to the night music of today, this was organised during the daylight, after lunch, with a Roman Catholic mass before.

One element of continuity from the past is the organisation of the šagre, especially in places where the young people are in charge of them. Still, most of the observed šagre tend to imitate the past events with the local popular music, mostly limited to the taste of older generations. However, in some observed studycases of the šagre, young people were in charge of their organisation. As an informant noted, not only folk music should be present at these events, since the mu-

${ }^{6}$ Interview by Petra Kavrečič, 22th August 2019. sic should suit to the tastes of all generations: 'it does not matter what music is played ... but it should be a little bit of all ... not only rock."7

The cases of šagre with music answering to the needs of the younger generation seem to be successful, especially those with the music that does not derive from the popular kind. Such is the case of črna šagra or black šagra in Pobegi with the concerts of metal music. The event was organized a day before the 'traditional' šagra with the aim of linking the so-called 'black' one and the traditional 'coloured' one. After two years the 'black' šagra surpassed the number of the visitors of the traditional šagra, which could indicate a success when tradition is adapted to the needs of the present or to those who will become the future bearers of tradition - young people. Similar was the event entitled 'the youth in Smokvica' with electronic music, which was consciously organised apart from the date of traditional šagra, but it was still perceived by people as šagra. In both cases, the events organized by village youth were supported by older village people, who expressed their satisfaction because 'something is happening in the village. ${ }^{8}$ As already said, if tradition does not adapt to the needs of the present, if it loses its meaning and disappears. This will probably not be the case of the šagre of the youth, where tradition fully answers to the needs of the present and (probably) the future bearers of tradition.

The element of šagre that was highlighted by most of the interlocutors of the previous and contemporary research was the function of the first dance or dance in general. It is in this case that the cohesive role of tradition takes place (Fakin Bajec, 2011, pp. 287291). Before globalisation processes, šagre were one of the rare occasions where young couples could meet and express their mutual affection by the official 'first dance.' One can say that this cohesive function of $\check{s} a$ gre has been retained only in places, where they are organised by youth, but in contrast to the past, it is no longer the prevalent function of šagre. The need for social encounters in fulfilled on many other occa-

\footnotetext{
${ }^{7}$ Interview by Petra Kavrečič, 22th August 2019.

${ }^{8}$ Interviews and both field research made by Jaka Godeša, 16th of August 2019 and 2nd of August 2019.
} 
sions. As observed during the ethnographic fieldwork, it seems that today, the main social gathering at the šagra is meant for families, children, and neighbours that meet at the festivity. Food and beverage are, of course, offered and consumed. It is an occasion for locals to socialize. There is music, but the dancefloor is not crowded. Dancing is not the primary purpose of the šagra anymore.

A difference with the šagre in the past is also represented by the food. While in the past only wine was offered (with the exception of some osmicas ${ }^{9}$ ), food was offered only in the intimacy of the family and the visiting relatives. For those days 'they did their best to offer the best they had' (Hrobat Virloget, 2012, p. 20) or as another informant commented, 'something better than usually was on the table.' Ethnologists as much as our informants were well aware of the changes in the 'traditional food.' What seems as traditional today was not necessary so in the past, as an informant commented, 'once there was not this habit of the tomato in the salad. Once, it was before the war. My uncle was a carabiniere [Italian police] in Italy and he used to eat this kind of tomato.' ${ }^{10}$

As seen in this case, the food has many symbolic functions in the cultures in which it is created. In line with the changing cultural patterns (through space and time), the eating habits of the members of a particular culture or community also change. The food and the ways of its preparation are not a static, unchangeable phenomenon, as they adapt to different influences, acquiring new characteristics over time (Kavrečič, 2014, p. 37). What seems today 'newly imported, will be probably tradition in the future as most of the cultural processes have been 'invented' or 'reinvented;' therefore there is no need to, distinguish between more and less ancient tradition (Mugnaini, 2004, p. 57; Hobsbawn \& Ranger, 1983). That

\footnotetext{
${ }^{9}$ Osmica represents the right to sell home made products as wine, later also food for a limited number of days (initially for eight days - that is why the name osmica - osem means eight in Slovene language). This right was obtained for the peasants during the Habsburg period (Hrobat Virloget, Kastelic and Kavrečič, 2012, pp. 65-66).

${ }^{10}$ Interview by Katja Hrobat Virloget, 4th July 2019.
}

is why, regardless of the guidelines for the so-called 'authenticity' (Sedmak, 2012) and regardless of the average perception of 'traditionality', čevapčiči is one of the most common food on šagre, as it has been most common on the public and private gatherings in (post)socialist Yugoslavia (Habinc, 2014, p. 121). Its seems that there is no Slovene family picnic or birthday celebration during warmer months without čevapčiči. This has also been successfully targeted by advertising of food-chain companies. Every end of April (towards the 1st May Holidays) as well as in summer months, the companies compete with one another for 'the best' offers of čevapčiči and similar food. The fact that before such holidays food and butcher shops usually run out of such products shows that this dish has been commonly accepted by Slovenes. However, knowing that tradition is changeable, invented, revived, forgotten in the constant adaptation to contemporary needs of the present, it would be nonsense to judge the 'import' of new food or drinks as some sort of 'terrible contamination.' Čevapčiči can be compared to discourses about burek, a similar 'imported' food from the Balkans, in which Jernej Mlekuž finds the representations of the Otherness, Balkanness, orientalness, although at the same time is perceived as 'foreign, but still “ours”' (Mlekuž, 2008; Janović, 2008). Although, čevapčiči seem to have accomplished a more efficient integration in the Slovene society and daily dish. When talking to the interlocutors, they made it clear that 'of course, we serve čevapčiči at šagra ... what else?" ${ }^{11}$ Čevapčiči are considered to be an integral part of the offering at this festivities.

Nowadays šagra food represents an important component of the festivity. It is important that the dish is prepared quickly and in abundance. Čevapčiči seems to have gained more success integrating into Slovene food habits than burek has, probably also because its easier preparation. Nowadays čevapčiči are not made at home but already prepared to be grilled, which provides them an advantage compared to other dishes.

However, in the observation of the traditional festivities in Istria we are again faced with an eternal dilemma in ethnology and cultural anthropology: to

\footnotetext{
${ }^{11}$ Interview by Petra Kavrečič, 22th August 2019.
} 
act in an applicative way, to judge (as expected from an ethnologist) what is truly traditional (cf. Poljak Istenič, 2008, 75; Habinc, 2014, p. 114), thereby creating or inventing heritage, or to critically observe from a distance how the society today 'thinks' heritage (Fakin Bajec, 2011, p. 13). At the festival of wine called Fontana fest in Marezige, ${ }^{12}$ it can be difficult to avoid judging as kitsch the presentations of the 'old days' such as the classic cars and old imported American bus or even the so-called traditional 'Šavrinke and Šavrini,' dressed in folk costume from last century, a typical form of folklorisms condemned as a 'distortion of folklore or "fakelore"” (Poljak Istenič, 2012, 84).

However, as the critics of the concept of folklorism have shown all the cultural forms, including the 'authentic' ones, remain 'constructions' (Bausinger, 2004, pp. 145-159; Mugnaini, 2004, p. 41). Furthermore, the concepts of 'authentic' and 'non-authentic' are reversed over time (Dei, 2002, p. 32). The term 'authenticity' today remains limited only to the field of tourism, where it implicates traditional culture, the feeling of originality, reality or uniqueness and where it gives sense to the experiences of tourists since tourist places are perceived as constructed, as a staged scene, with a 'staged authenticity' (Poljak Istenič, 2013, pp. 103-108). Ahmed Scounti defines these kinds of heritage performances as 'authentic illusions,' which are similar to 'the inventions of traditions' (Hobsbawm \& Ranger, 1983). As intangible heritage has no authenticity, if this is conceived as rootedness, faithfulness or fixedness, since it changes, it is fluid, it is never performed identically, it is re-created, it has different application within communities, it has different meanings for different people, etc. If we want to fix it or materialize it, we just make a certain copy in a certain time, but we cannot guess the forms it will take through time (Scounti, 2009, p. 78). With tradition, 'communities and individuals think of their past, present and future' (Slavec Gradnišnik, in print). Tradition is not what people passively accept from the past and what it has always been, but is the viewpoint, the perception of the contemporary people of what the past was. It is, therefore, an interpretation of

${ }^{12}$ Fieldwork done by Jaka Godeša 9th June 2019. the past according to the strictly contemporary criteria. As Gérard Lenclud summarises, 'tradition is not what it always was, but what is made of it' (Lenclud, 2004, p. 131). According to Herman Bausinger, the socalled 'non-authentic' has to enter into the research field of the ethnologist to help him/her understand the processes of constructing the social meaning of the phenomenon and its role in organising social bonds (Bausinger, 2004, pp. 145-159; Mugnaini, 2004, p. 41). If we reflect on the popular regional symbol of 'Šavrini' presented in Marezige's festival, it has to be understood as a form of an invented identity from the 199os, the consequence of the Slovenisation and nationalisation of the newly Slovenian Istria (Brumen, 2000, p. 404; Baskar, 2002, p. 120). Today, it reflects the 'façade of the tourist image' (Ledinek Lozej \& Rogelja, 2012, p. 544 ) and 'a nostalgic search for lost time and authentic life' (Ledinek Lozej \& Rogelja, 2012, p. 544). As Mateja Habinc observes, cases such as this show that authenticity is not only a fiction, as described above, but it is also a reality based on the organizers' discourse, a social fact affecting social practice, which is therefore changeable through time (Habinc, 2014, p. 115; Ceribašić, 2008, pp. 261-262).

\section{Problems of Dis-Continuity?}

If we have shown some elements of continuity through time in the village festivities of šagre while being well aware that continuity does not mean sameness, but adaptation and changeability through time, the question goes to a thus far mostly ignored question of the continuity of the tradition in Istria in places, where 'old people' have gone away. When we asked our interlocutors why the traditional village festivities like šagre have died out, usually the answer would be as the one from Manžan: ${ }^{13}$

I1: These people from this village went to Izola, Koper, Trieste, Italy, they went left and right, and the village remained empty. [...] You know what they got, that Italians from Koper and Izola, they went to Trieste, and these [e.g., people settling in the emptied towns after Italians 
left] they got these old big houses, the old ones, they got farms in Koper, they left this and went from Marezige, Manžan, all these villages. They got and went away [...] And at that time the village, at least Manžan, has emptied out.

$\mathrm{K}$ : And who came here?

I2: People from the south [e. g. From ex Yugoslavian republics other than Slovenia] ... a feeling of loneliness among the newcomers in the village was felt further on.

The older married couple from Manžan commented that all these forešti, meaning strangers, not locals, are not interested in the local tradition: ${ }^{14}$

I1: Once our daughter, they thought of organizing a šagra. [...] But what if here is everything mixed [meaning locals and migrants]. But then nothing happened. [...] Nothing was done.

I2: There was no interest.

I1: These forešti [foreigners]. There was no interest.

Similar was the answer of another informant from Zabavlje ${ }^{15}$ on the question why the commemorations by the local monument of the national liberation struggle are no longer organised anymore: 'Today, there are other people in the village, only a few locals, they came from elsewhere. They are all fine, they have adapted, but they still do not feel the same as I do living here. ${ }^{16}$ Kennell, Šuligoj, and Lesjak (2018) claim that these highly significant occasions for local communities might not be understood by visitors, which can be evidently applied also to immigrants.

From these interviews, two problems can be discerned. The first is the break in the continuity of village traditions due to migrations, with the consequence of the disappearance of the 'traditional' demographic village structure. This problem has been mostly ignored until now. The prevalent perception of the hinterland of the Istrian towns was usually linked to the continuity of the inhabitants in contrast to the demographic

\footnotetext{
${ }^{14}$ Interview by Katja Hrobat Virloget, 4 th July 2019.

${ }^{15}$ Interview by Jaka Godeša, 28 of July 2019.

${ }^{16}$ Interview by Jaka Godeša, 28th July 2019.
}

structure of the urban population of the Istrian towns, which was more widely known, at least in Istria, to have changed after wwir. According to the data of Slovenian authorities with the so-called 'Istrian exodus $^{17} 27,810$ people left the areas of Istria that came under Slovenian jurisdiction between 1945 and 1958; they were mostly Italians, but also Slovenians and Croats (Cunja, 2004, p. 89; Troha, 1997, p. 59) (from a total of between 200,000 and 350,000 migrants from the whole Istria; Ballinger, 2003, pp. 1, 275). Especially the villages closer to the Italian border were faced with mass migration:

Almost everybody left ... only ten families remained ... my wife also wanted us to leave and I already sold all my belongings ... but then I looked at the other side ... people [that moved to the emigrant's camps nearby, in Milje] lived in poor conditions ... I couldn't leave my home... so I have stayed and bought everything back [furniture, livestock ...].

Some of the observed cases show even some revitalisation processes of šagre after the tradition disappeared for some decades due to the lack of interest of the young generation and the migration processes. Such is the case of the revival of the July šagra in and and 3rd Škofija (Zgornje Škofije) in 2004. The locals (not only the younger) gathered and until 2011 organized the šagra that had disappeared during the 1950s, since most of the 'old' villagers left for Italy: 'it was very nice ... a lot of people came ... but then we stopped ... there is no people who would work [take care of the organization] ... young people were not interested ...

${ }^{17}$ The Istrian exodus was the final stage of Italian migration from Yugoslavia, which started shortly after the war ended, when the Yugoslav national liberation army occupied the territories along the Adriatic coast (Istria, Dalmatia), assigned to the Kingdom of Italy after the fall of the Austro-Hungarian empire (Treaty of Rapallo 1920). Some more research has been done on the Istrian exodus, but in a much smaller scale on the migration processes after 'exodus' (Gombač, 2005; Ballinger, 2003; Verginella, 2015; Hrobat Virloget, Gousseff \& Corni 2015; Kalc, 2019; Titl, 1961, etc.). 
we [the elders] had to prepare and clean everything.' ${ }^{18}$

Besides the lack of interest of the young people in the organisation of the šagra, the problems of mass migrations after WWII and successive immigrations were exposed: 'here there is a lot of immigrants ... there is a few families left ... most of them went to Italy or already died ... the problem is also politics ... different political opinions and people do not want to collaborate ... this is not good ... it should be neutral. ${ }^{19}$

In 1960, a few years after the final phase of the exodus, the proportion of native residents in the Slovenian part of Istria dropped to $49 \%$, according to registry offices, reaching $65 \%$ in rural areas and $33 \%$ in urban areas. The difference is accounted for by the fact that the Italian population was concentrated in urban areas, while the adjacent rural population was largely Slovene (Titl, 1961; Kalc, 2019). ${ }^{20}$ The Yugoslav authorities filled the void that remained in the urban areas after the Italians had left by stimulating the inflow of people from inland Slovenia and the rest of $\mathrm{Yu}-$ goslavia, which has completely changed the ethnic, social, and cultural face of Istria (Gombač, 2005, p. 11). ${ }^{21}$ The interviews show that not only inhabitants of the urban areas left, but also those from the rural, while the emptied places in the towns were settled by the Istrians from their rural surrounding (Hrobat Virloget, 2019). The process of emigration was, as it always is, highly complex, manifesting as a consequence of political, economic and social causes.

In order to minimise or relativize the effects of the 'Istrian exodus' historical discourses have emphasised the urban character of the Italians against the rural Slavic population, which was a nationalistic construct

${ }^{18}$ Interview by Petra Kavrečič, 22th August 2019.

${ }^{19}$ Interview by Petra Kavrečič, 22th August 2019.

${ }^{20}$ In Istrian towns the total registered population of ethnic Italians dropped from $90 \%$ before the war to a mere $7.7 \%$ in Koper/Capodistria, $8.15 \%$ in Izola/Isola, and $15.7 \%$ in Piran/Pirano in 1957 (Troha, 1997, p. 59).

${ }^{21}$ We are well aware that other more or less massive migrations have affected this contested border region from 19th century onwards due to several changes of political powers, ideologies and sovereignties, but since our research is limited to the recent traditions, our focus goes to the correlated period. of the 19th century. New research has deconstructed this ethnic/nationalistic dichotomy, showing a much more complex socio-historical situation (Dota, 2010, p. 63; d'Alessio, 2003; on problematic national identity in Istria see Pupo \& Panjek, 2004, p. 352; Ballinger, 2006; Brumen, 2000; 2001; D'Alessio, 2006; Hrobat Virloget, 2015, pp. 162-164). However, coming back to the observed problem of discontinuity, the most recent research on the migration processes after 'exodus' in Istria has showed, that in the first wave of the 'exodus', the emptied Istrian towns after 'exodus' were settled by people from the neighbouring environment, from Istria and the wider region of Primorska (Hrobat Virloget, 2019; Kalc, 2019). The current research focusing on tradition proves again, that tradition cannot be researched apart from its social and historical context. The old cultural-historical perspective in ethnology and cultural anthropology has been replaced by perspectives focusing on agency, in from which the attention goes to dynamic processes of creations, implementation, agency, praxis, etc. (Habinc, 2008, p. 322). From this perspective, the present research indicated that one of the most decisive factors in the questions of dis-continuity or disappearance of traditions in the Istrian hinterland was played by (massive) migrations, which were until now totally overlooked, at least when speaking of the non-urban environment.

The second reason for the dying of tradition in the Istrian country-side linked to the migrations and indicated by the interlocutors is the absence of the identification of the settlers with the new environment. The new paradigm emphasis the cohesive role of tradition in which it is perceived as a medium that enhances the sense of belonging and mobilises the individual within it (Poljak Istenič, 2012, p. 88; Fakin Bajec, 2011, pp. 287-291). Jasna Fakin Bajec noted that people do not preserve tradition because they would like to preserve the past (as the expectation of the professionals would be), for market purpose (tourism) or for identification purposes, but because of their current social needs for gathering, fun, and conversations (Fakin Bajec, 2011, pp. 287-291). If people do not need to identify with the village community and gather with the members of it, especially in the contemporary individually oriented society, there is no need for tradition. The 
fieldwork has shown that the problem of discontinuity of tradition in some Istrian villages is linked to the disinterest of the new settlers in actively taking part in the village traditions, and in actively taking part of the village community. This can also be explained by the individualistic and frenetic way of life of today.

\section{A Remark on Šagre and Tourism}

Tourism is an activity that provides substantial financial income, and it is one of the fastest-growing industries in the world (Kavrečič, 2017, p. 19). It has excellent capabilities to adjust to latest trends and needs. If is the sun and the sea, it will promote sun and swimming localities; if it is curiosity for heritage and way of living of the visited destinations, its offering and supply will adjust to that demand. In recent years, a great effort has been made towards heritage tourism, emphasising the natural and cultural resources ${ }^{22}$ of the visited areas. In the case of North Istria, we were also interested in peoples' perception of touristic activities linked to the intangible heritage such as šagre. Our research has shown that šagra events do not have a tourist affiliation. Locals mostly want to maintain a local characteristic, and their purpose is to gather the inhabitants of the village (and surrounding communities). They are an opportunity for locals to meet and socialize. As an informant said: 'for the rural area ... šagra ... and I like it to stay this way, since the city is something different. Here are more local people [that come at šagra], although people are also coming from other places, because they have means of transport. ${ }^{23}$ However, tourists are not seen as participants at such events.

In contrast, there are events - mostly new - that have overcome the local affiliations and gained a more 'touristic' character. Such events (as Praznik refoška or Fontana fest in Marezige) are seen differently by the locals: ${ }^{24}$

\footnotetext{
${ }^{22}$ Heritage tourism aims at promoting 'traveling to experience the places, artefacts, and activities that authentically represent the stories and people of the past and present. It includes cultural, historic and natural resources' (National Trust for Historic Preservation, 2015; Gibson, 2015).

${ }^{23}$ Interview by Jaka Godeša, 28th July 2019.

${ }^{24}$ Interview by Jaka Godeša, 28th July 2019.
}

when you visited šagra you met a lot of people, it took place in the local area, but today Praznik refoška is losing its cosiness. At the beginning, the locals voluntarily organized the event, my mum, I know, she baked bread ... every woman baked something ... but today, it is only commercial, they sell different things, busses [are arriving], the restaurant ... it is all for money.

We can see the difference between the festivities. On one side there are the ones (šagra) that have a more local character and have no interest in tourist promotion, on the other, there are 'massive' events that are in fact trying to attract also tourists by selling products, presentation of 'old days' customs, dresses etc. that represent a 'staged authenticity'. Both types can be linked with some kind of nostalgia and especially the least ones with (trendy) special interest tourism (Šuligoj, 2018).

\section{Concluding Remarks}

This paper presents an analysis of the conducted study and ethnographic fieldwork on intangible heritage of North Istria that took place in the frame of the project Turizmo Ištriano (Programme LAs Istre). The main focus of the research was on traditional festivities, especially šagre in the region, which when speaking of the traditional village festivities, were the most mentioned by our interlocutors. The issues raised have brought out questions of the so-called 'authenticity' and continuity or discontinuity of the intangible heritage in North Istria, which had not been questioned before.

The question - Why have certain traditional festivities in North Istria have disappeared and why others have persisted? - can be only partially answered. The research has shown that a significate element of the break of tradition of šagre can be found in the massive migrations after WWII in the rural part of Istria, which is related to the consequences of the so-called 'Istrian exodus.' The finding is quite innovative, since in the dominant discourses the massive migrations were mostly linked to urban areas, to Istrian towns, but no reflection had previously been done on their impact in the rural part of Istria. The second reason 
for the discontinuity of tradition in some Istrian villages is linked to the disinterest of the new settlers in actively taking part in the village traditions, and in actively being apart of the village community. Younger people do not integrate into the villages, since they commute to work to the urban areas, and the village is mostly considered a place to sleep. In this period of capitalistic euphoria and the consumer society, nothing is done for free. Thus, migrations could be seen as one of the strong reason for the break in the traditions in Istria, in one way due to the disappearance of the 'bearers' of tradition with the 'exodus', and on the other way due to the disinterest in the maintenance of traditions of the new settlers, coming after 'exodus' or in more recent decades.

The research has also shown cases of continuity of šagre, which seems to be much stronger when the active part of its organisation is taken charge by young people, the future bearers of tradition. It has been shown how necessary the tradition's adaptation to the contemporary needs of the present is in order for it to survive; in the observed cases, this has affected the choice of music for the taste of the youth (or all generations together) or with the adaptation to the popular, even though 'non-authentic' food.

In conclusion, a short reflection has been done on the problem of the correlation between traditional local festivities and the tourism industry. Which events are potentially attractive for tourists and which are eager to obtain a more local characteristic, but this time with the focus on the perspective of the locals the Istrians? It has been shown that people do differentiate between two types of festivities, those (řagra) that have a more local character and in reality do not have any interest in being part of tourist promotion, on the other, the 'massive' events, that are in fact trying to attract also tourists by selling products, presentation of 'old days' customs, costumes, etc., that represent a 'staged authenticity.' From the point of view of the locals, dissatisfaction with the 'massive' festivities for tourist aims was noted, while a desire was observed to maintain the local characteristics of $\check{s} a$ gre gathering only the inhabitants of the village and surrounding communities. As it seems tradition has been still valued due to its function of cohesive role among people of the village and region, regardless of its (dis)continuity, 'old' or 'new' imported forms.

\section{Acknowledgments}

We thank Jaka Godejša, a student of the Faculty of Tourism study-Turistica, for his participation in the fieldwork. His work was very accurate, and his interviews and observations represent an essential contribution for this research.

\section{References}

Ballinger, P. (2003). History in exile: Memory and identity at the borders of the Balkans. Princeton, NJ: Princeton University Press.

Ballinger, P. (2006). Opting for identity: The politics of international refugee relief in Venezia Giulia, 1948-52. Acta Histriae, 14(1), 115-140.

Baskar, B. (2002). Dvoumni Mediteran. Koper, Slovenia: Zgodovinsko društvo za južno Primorsko.

Bausinger, H. (2004). Per una critica alle critiche del folklorismo. In P. Clemente and F. Mugnaini (Eds.), Oltre il folklore: Tradizioni popolari e antropologia nella società contemporanea (pp. 145-159). Rome, Italy: Carocci Editore.

Brumen, B. (200o). Sv. Peter in njegovi časi. Ljubljana, Slovenia: ${ }^{\star} \mathrm{Cf}$.

Brumen, B. (2001). Avant, on était tous simplement des Istriens: Lémergence de nouveaux repères identitaires dans un village frontalier de Slovénie. In C. Bromberger and A. Morel (Eds.), Limites floues, frontières vives: Des variations culturelles en France et en Europe (pp. 343359). Paris, France: Maison des sciences de l'homme.

Ceribašić, N. (2008). Folklor i folklorizam. In A. Muraj and Z. Vitez (Eds.), Predstavljanje tradicijske kulture na sceni i u medijima (pp. 259-270). Zagreb, Croatia: Institut za etnologiju i folkloristiku / Hrvatsko etnološko društvo.

Ciglič, Z. (1981). Ljudsko izročilo na območju Marezig. In Marezige - simbol upora: 1921-1981 (pp. 79-94). Koper, Slovenia: Založba Lipa.

Cunja, L. (2004). Škofije na Morganovi liniji. Koper, Slovenia: Založba Lipa.

D’Alessio, V. (2003). Il cuore conteso: Il nazionalismo in una comnità multietnica; L'Istria Asburgica. Naples, Italy: Filema.

D'Alessio, V. (2006). Istrians, identifications and the Habsburg legacy: Perspectives on identities in Istria. Acta Histriae, 14(1), 15-39.

Dei, F. (2002). Beethoven e le mondine: Ripensare la cultura popolare. Rome, Italy: Meltemi. 
Dota, F. (2010). Zaraćeno poraće: konfliktni i konkurentiski anrativi o stradanju $i$ iseljavanju Talijana iz Istre. Zagreb, Croatia: Srednja Evropa.

Fakin Bajec, J. (2011). Procesi ustvarjanja kulturne dediščine: Kraševci med tradicijo in izzivi sodobne družbe. Ljubljana, Slovenia: Založba zRC SAzU.

Habinc, M. (2008). Koledarski prazniki: Niko Kuret, tvornost in političnost praznikov. In I. Slavec Gradišnik (Ed.), Čar izročila: zapuščina Nika Kureta (pp. 303-318). Ljubljana, Slovenia: zRC sAzU.

Habinc, M. (2014). Intangible culture as tradition: The cows' ball, the village serenade and the country wedding in Bohinj. Narodna umjetnost, 51(1), 113-129.

Hobsbawm, E., \& Ranger, T. (Eds.) (1983). The invention of tradition. Cambridge, England: Cambridge University Press.

Hrobat Virloget, K. (2012). Šagre v Istri: etnološki pogled. In A. Panjek (Ed.), Istrski praznik: preteklost, sedanjost, avtentičnost: šagre in ljudski prazniki v severni Istri (pp. 14-24). Koper, Slovenia: Annales.

Hrobat Virloget, K. (2015). The burden of the past: Silenced and divided memories of the post-war Istrian society. In K. Hrobat Virloget, C. Gousseff \& G. Corni (Eds.), At home but foreigners: Population transfers in 2oth Century Istria (pp. 159-188). Koper, Slovenia: Annales.

Hrobat Virloget, K. (2019). The 'Istrian exodus' and the Istrian society that followed it. Dve domovini: razprave o izseljenstvu, 49, 163-180.

Hrobat Virloget, K., Kastelic, E., \& Kavrečič, P. (2012). Sodobne »tradicionalne " prireditve v severni Istri s stališča predstavitve dediščine. In A. Panjek (Ed.), Istrski praznik: preteklost, sedanjost, avtentičnost: šagre in ljudski prazniki v severni Istri (pp. 54-74). Koper, Slovenia: Annales.

Gibson, J. (2015). Today's word: Heritage tourism. Retrieved https://savingplaces.org/stories/preservation-glossarytodays-word-heritage-tourism\#.XXH-CSgzZPY

Gombač, J. (2005). Ezuli ali optanti? Zgodovinski primer $v$ luči sodobne teorije. Ljubljana, Slovenia: Založba ZRC.

Janović, N. (2008). Jernej Mlekuž, Burek.si?! Koncepti/recepti. Dve domovini, 28, 169-171.

Kalc, A. (2019). The other side of the 'Istrian exodus:' Immigration and social restoration in Slovenian coastal towns in the 1950s. Dve domovini, 49, 145-162.

Kavrečič, P. (2014). Interpretacija istrske hrane: od osnovne življenjske potrebe do dediščine. Glasnik Slovenskega etnološkega društva, 54(4), 37-42.

Kavrečič, P. (2017). Turizem v Avstrijskem Primorju: zdravilišča, kopališča in kraške jame (1819-1914). Koper, Slovenia: Založba Univerze na Primorskem.
Kennell, J., Šuligoj, M., \& Lesjak, M. (2018). Dark events: Commemoration and collective memory in the former Yugoslavia. Event Management, 22(6), 945-963.

Kockel, U. (2008). Putting the folk in their place: Tradition, ecology, and the public role of ethnology. Anthropological Journal of European Cultures, 17(1), 5-23.

Koštiál, R. (2005). Šege in navade v Rakitovcu v 20. stoletju. In V. Rožac Darovec (Ed.), Meje in kofini (pp. 169-228). Koper, Slovenia: Annales.

Kuret, N. (1998). Praznično leto Slovencev (Vol. 2). Ljubljana, Slovenia: Družina.

Ledinek Lozej, Š., \& Rogelja, N. (2012). Šavrinka, Šavrini in Šavrinija v etnografiji in literaturi. Slavistična revija, $60(3), 537-548$.

Lenclud, G. (2004). La tradizione non è più quella d'un tempo. In P. Clemente \& F. Mugnaini (Eds.), Oltre il folklore: Tradizioni popolari e antropologia nella società contemporanea (pp. 123-134). Rome, Italy: Carocci Editore.

Mlekuž, J. (2008). Burek.si?! Koncepti/recepti. Ljubljana, Slovenia: Studia Humanitatis.

Mugnanini, F. (2004). Introduzione: Le tradizioni di domani. In P. Clemente \& F. Mugnaini (Eds.), Oltre il folklore: Tradizioni popolari e antropologia nella societa contemporanea (pp. 11-72). Rome, Italy: Carocci Editore.

Muženič, M. (2012). Zgodovinske prvine šager in ljudskih praznikov v severni Istri. In A. Panjek (Ed.), Istrski praznik: preteklost, sedanjost, avtentičnost: šagre in ljudski prazniki v severni Istri (pp. 88-94). Koper, Slovenia: Annales.

Poljak Istenič, S. (2008). Šege in navade kot folklorizem. Traditiones, 37(2), 61-110.

Poljak Istenič, S. (2012). Aspects of tradition. Traditiones, $41(2), 77-89$.

Poljak Istenič, S. (2013). Tradicija v sodobnosti: Janče - zeleni prag Ljubljane. Ljubljana, Slovenia: Založba zRC.

Pupo, R., \& Panjek, A. (2004). Riflessioni sulle migrazioni al confine Italo-Jugoslavo (1918-6o). In C. Donato, P. Nodari, \& A. Panjek (Eds.), Oltre l'Italia e l'Europa: Ricerche sui movimenti migratori e sullo spazio multiculturale (pp. 343-360). Trieste, Italy: Edizioni Università di Trieste.

Scounti, A. (2009). The authentic illusion: Humanity's intangible cultural heritage, the Moroccan experience. In L. Smith \& N. Akagawa (Eds.), Intangible heritage (pp. 74-92). London, England: Routledge.

Sedmak. G. (2012). Podlage in smernice za trženje šager in ljudskih praznikov. In A. Panjek (Ed.), Istrski praznik: preteklost, sedanjost, avtentičnost: šagre in ljudski prazniki v severni Istri (pp. 76-87). Koper, Slovenia: Annales. 
Sims, M., \& Stephens, M. (2005). Living folklore: Introduction to the study of people and their traditions. Logan, U T: Utah State University Press.

Slavec Gradnišnik, I. (In print). Več kakor eni drugi človik. In B. Jezernik \& I. Slavec Gradišnik (Eds.), Močni, modri, in dobri; junaki $v$ slovenski folklori. Ljubljana, Slovenia: Znanstvena založna Filozofske fakultete Univerze v Ljubljani.

Šuligoj, M. (2018). Characterising the flows of Slovenian tourists within the former Yugoslavia with respect to post-communist 'nostalgic context.' Moravian Geographical Report, 26(1), 14-26.

Titl, J. (1961). Populacijske spremembe v Koprskem primorju: Koprski okraj bivše cone B. Koper, Slovenia: Author.

Troha, N. (1997). s тo - Svobodno tržaško ozemlje. In S. Valentinčič (Ed.), Zbornik Primorske - 50 let (pp. 566o). Koper, Slovenia: Primorske novice.
Verginella, M. (2015). Writing historiography on migrations at the meeting point of nations in the Northern Adriatic. In K. Hrobat Virloget, C. Gousseff, \& G. Corni (Eds.), At home but foreigners: Population transfers in 2oth Century Istria (pp. 49-70). Koper, Slovenia: Annales.

Vidali, R. (1989). Čubejske žrjavce. Koper, Slovenia: Revija Fontana.

Vilfan, S. (1945). Žegnanja v slovenski pravni zgodovini. Etnolog, 17, 16-27.

Vilfan, S. (1996). Pravna zgodovina Slovencev. Ljubljana, Slovenia: Slovenska matica.

Župnija Koper (B. d.). Cerkev Kristusa Kralja. Podružnična cerkev Kristusa Kralja na Zgornjih Škofijah. Retrieved from https://skofije.donbosko.si/cerkev-kristusa-kralja

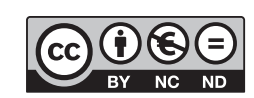

This paper is published under the terms of the Attribution- NonCommercial-NoDerivatives 4.0 International (CC B Y-NC-ND 4.0) License. 